\title{
TITLE:
}

\section{Efficacy of Tocilizumab in Covid 19: A metanalysis of case series studies}

Shalam Mohamed Hussain, ${ }^{1 *}$ Ayesha Farhana Syeda ${ }^{2}$, Osama Al-Wutayd, ${ }^{3}$ Abdullah Al Nafeesah, ${ }^{3}$ Mohammad Alshammari, ${ }^{4}$ Sulaiman Alnasser, ${ }^{5}$ Nandakumar Krishnadas ${ }^{6}$

1 Former faculty and independent reseaarcher, College of Pharmacy, Qassim University, Saudi Arabia

2 Department of Pharmaceutics, Unaizah College of Pharmacy, Qassim University

3 Department of Family and Community Medicine, Unaizah College of Medicine and Medical Sciences, Qassim University, Saudi Arabia.

4. Department of Pediatrics, Unaizah College of Medicine and Medical Sciences, Qassim University, Saudi Arabia.

5 Department of Pharmacy Practice, Unaizah College of Pharmacy, Qassim University

6 Department of Pharmacology, Unaizah College of Pharmacy, Qassim University

76 Department of Pharmacology, Manipal College of Pharmaceutical Sciences, India 
medRxiv preprint doi: https://doi.org/10.1101/2020.08.12.20173682; this version posted August 15, 2020. The copyright holder for this preprint (which was not certified by peer review) is the author/funder, who has granted medRxiv a license to display the preprint in perpetuity.

It is made available under a CC-BY-ND 4.0 International license .

\begin{abstract}
Background : characteristic feature of COVID-19 during its progression in severity is the cytokine storm (via interleukin-6, IL-6) which is responsible for secondary acute respiratory distress syndrome (ARDS) [4]. Tocilizumab has an antagonist effect on the IL-6 receptor. With present review and metanalysis, we intend to update the current status on the clinical efficacy of tocilizumab in the treatment of Covid 19 infections in the published literature of case series. MATERIALS AND METHODS: The following inclusion criteria were used: (i) case series studies (number of reported patients in each study equal to or greater than ten (ii) use of tocilizumab alone or in combination with standard of care therapy (iii) Covid 19 adult patients (iv) the studies with endpoints on all-cause mortality, need for mechanical ventilation, clinical improvements. Data synthesis and statistical analysis Meta-analysis was performed using a random effects model and the DerSimonian and Laird method. RESULTS 18 were selected for the quantitative analysis (meta-analysis). 14 studies were retrospective and 4 were prospective Meta-analysis The mortality rate of COVID-19 patients with tocilizumab was $21 \%$ (251/1212) Asymmetric funnel plot in the cylindrical form due to publication bias In conclusion the present synthesis provide us useful insights with the other available evidence to refine our strategy and equip ourselves effectively with tocilizumab to defeat COVID 19 to save humanity. Limitations The included studies utilized varied doses of tocilizumab (single or double), and duration drug availability issues emerged in some centers, which may have influenced both sample sizes and study designs. Clinical implications: Incorporated studies without control groups into systematic reviews and quantitative synthesis especially when there are no other studies to consider can provide information for formulating effective treatment strategies for management of COVID 19 infections through the use of tocilizumab.
\end{abstract}

Key words: COVID 19; tocilizumab, interleukin-6, cytokine storm, case series 
medRxiv preprint doi: https://doi.org/10.1101/2020.08.12.20173682; this version posted August 15, 2020. The copyright holder for this preprint (which was not certified by peer review) is the author/funder, who has granted medRxiv a license to display the preprint in perpetuity.

It is made available under a CC-BY-ND 4.0 International license.

\section{Introduction}

Since December 2019, when in Wuhan, China, coronavirus disease 2019 (COVID-19) first identified, has spread rapidly in many countries seriously impacting the global economy[1]. Apart from the classically known symptoms of COVID-19 fever, cough, and shortness of breath several studies discovered additional clinical manifestation of the disease was such as fatigue, myalgia, increased septum production, chest pain, chill), headache, sore throat and diarrhea[2]. The Centers for Disease Control and Prevention (CDC) also added new symptoms including new loss of taste or smell, repeated shaking with chills, and sore throat. A characteristic feature of COVID-19 during its progression in severity is the cytokine storm (via interleukin-6, IL-6) which is responsible for secondary acute respiratory distress syndrome (ARDS)[2][3][4]. ARDS is the most devastating complication of SARSCoV-2 with a higher death toll[5][6]. The incidence of ARSD following COVID-19 is higher in severe cases. Hence treating cytokine storm has resulted in rescuing COVID19 affected patients. Currently, there is no specific drug for COVID-19 induced cytokine storm but the tocilizumab is a recombinant humanized monoclonal antibody that has an antagonist effect on the IL-6 receptor. It is currently used in the treatment of rheumatoid arthritis, but could also play a key role in treatment for severely ill patients with COVID-19[7][8]. Tocilizumab has received considerable attention in studies finding reduction in COVID-19 related deaths and morbidities. As the treatment of cytokine storm induced by COVID-19 with tocilizumab has broad prospects, it is been recommended in many countries as well as been used off label[9][10]. However, the clinical experience and data of tocilizumab in the treatment of COVID-19 are limited, despite several reviews and metanalyses about its use in COVID 19. Though the randomized controlled trials (RCTs) provide rigorous results for effectiveness of any interventions, yet may not be the enough for all questions[11]. However, in this pandemic tiring times, difficult to complete and investigate the suitable remedies for COVID 19. It is also important to consider the best possible evidence in these difficult times to find solution for the devastating COVID 19.

Systematic reviews are an established approach to identifying and summarizing a body of literature associated with a particular topic area and meta-analysis (the formal statistical pooling of data from multiple studies), can be used to develop summary estimates for proportions from case series studies. Previous reviews and metanalyses on the utility of tocilizumab have explored on the available evidence of case control studies, a large body of evidence, such as case series, however, was left out. 
medRxiv preprint doi: https://doi.org/10.1101/2020.08.12.20173682; this version posted August 15, 2020. The copyright holder for this preprint (which was not certified by peer review) is the author/funder, who has granted medRxiv a license to display the preprint in perpetuity.

It is made available under a CC-BY-ND 4.0 International license .

Case series studies can also provide valuable additional evidence for practitioners and decision makers especially in this hard time of war like situation against COVID 19 pandemic[12][13]. Currently, there is no standardized method for synthesizing results of studies that do not have control groups but several studies published with case series have provided valuable insight into the decision-making processes. With present review and metanalysis, we intend to update the current status on the clinical efficacy of tocilizumab in the treatment of Covid 19 infections in the published literature of case series.

\section{MATERIALS AND METHODS}

\subsection{Literature search strategy}

A preliminary search conducted prior to formal literature review found limited evidence on the topic and yet patients being treated with tocilizumab, revealing an urgency in dealing with this issue. Therefore, the present endeavor is an attempt to contribute to enlighten the success against this growing menace. A literature search was conducted on PubMed, Google Scholar and repositories of preprints (MedRxiv) for articles published until July, 2020 using keywords such as "COVID-19," "tocilizumab," "interleukin 6 antagonist," or "IL-6 blocker", or "human monoclonal antibody," “cytokine storm treatment"). In Google scholar text word search of titles and abstracts was conducted using the following search terms 'Tocilizumab,' 'anti-interleukin-6 antibody,' and 'COVID-19' or 'coronavirus 2019' in various combinations. This meta-analysis was performed in accordance with preferred reporting items for systematic review and meta-analysis statement (PRISMA).

\subsection{Inclusion and exclusion criteria}

The following inclusion criteria were used: (i) case series studies (number of reported patients in each study equal to or greater than ten (ii) use of tocilizumab alone or in combination with standard of care therapy (iii) Covid 19 adult patients independently of the severity of their symptoms and (iv) the studies specified any or all of the following endpoints on all-cause mortality, need for mechanical ventilation, clinical improvements, ICU admissions, incidence of adverse outcomes, length of hospital stay (v) positive SARS-CoV-2 diagnosis by reverse-transcriptase polymerase chain reaction. The following outcomes were considered as clinical efficacy measurements: survival rate, resolution of symptoms and discharge from the hospital. No limits were applied to either date or language of the literatures published. Review articles, case reports with less than 10 cases, cases reporting pediatric or pregnant COVID 19 or organ transplanted patients were excluded from the quantitative 
medRxiv preprint doi: https://doi.org/10.1101/2020.08.12.20173682; this version posted August 15, 2020. The copyright holder for this preprint (which was not certified by peer review) is the author/funder, who has granted medRxiv a license to display the preprint in perpetuity.

It is made available under a CC-BY-ND 4.0 International license.

analysis. The articles, which were in the form of only abstracts, letters without original data, metaanalysis, animal studies, or studies that did not report original data on tocilizumab were excluded. Further attempts were made to identify relevant studies through references to find eligible studies. The flow of information from identification to inclusion of studies is summarized in figure 1.

\subsection{Data extraction}

A standard data extraction template was used by two authors independently to extract the following information from each included study: (1) article information (author and publication year, country, type of study, number of patients in tocilizumab groups, patients' gender, age, drugs used in standard of care, and mortality in both groups. (3) type of intervention; type, dose, duration, and frequency of administration of tocilizumab (4) type of outcome measure, mortality in severe COVID-19 patients who received tocilizumab, improvement proportions, number for mechanical intervention or ICU admissions. Secondary outcomes were proportions reporting any adverse events and time in days to recover or discharge. The characteristics of the studies extracted are shown in Table 1. The proportions of individuals meeting each outcome will be included in meta-analysis to provide summary estimates of proportions. Eligibility assessment was performed independently in an unblinded standardized manner by two reviewers. Disagreements between reviewers, if any, were resolved by consensus.

\subsection{Quality assessment of the included studies}

The quality of all studies was assessed independently by two reviewers using the "Quality Appraisal Checklist for Case Studies" tool developed by the Institute of Health Economics [11]

\subsection{Data synthesis and statistical analysis}

The primary outcome was the proportion of patients with COVID 19 who were being treated with tocilizumab. This was calculated as the number of patients being affected by the total number of cases of COVID 19. Standard errors and confidence intervals for a single proportion were derived. The derived proportions were adjusted by logit transformation. Meta-analysis was performed using a random effects model and the DerSimonian and Laird method. Random effect models and I-square $\left(\mathrm{I}^{2}\right)$ test were used to assess quantitatively the impact of anticipated study heterogeneity on the results of the meta-analysis. $\mathrm{p}$ value $<.1$ and $\mathrm{I}^{2+}$ value of $>50 \%$ were considered statistically significant. In proportional meta-analysis, a common challenge, that is faced is to deal with proportions when they 
medRxiv preprint doi: https://doi.org/10.1101/2020.08.12.20173682; this version posted August 15, 2020. The copyright holder for this preprint (which was not certified by peer review) is the author/funder, who has granted medRxiv a license to display the preprint in perpetuity.

It is made available under a CC-BY-ND 4.0 International license.

are too large or too small (close to 0 or to 1 ) which causes the variance of the proportion to be very small leading to an inappropriate large weight. To over this, a count of 0.5 was added to or subtracted from the number of COVID 19 cases to those reporting an outcome of $0 \%$ or $100 \%$ respectively and to conduct the meta-analysis by transforming the proportions using logit transformation[14][15]. Forest plot was generated to depict the logit proportion along with its $95 \%$ confidence interval for each study as well as the pooled them.

\section{RESULTS}

\subsection{Study selection}

The electronic search strategy retrieved from PubMed $(n=258)$ and Google $(n=275)$, preprints ( $n$ $=20)$ and other sources $(\mathrm{n}=20)$. From this 270 were left after removing duplicates. Following screening of title and abstracts $(n=67)$ were retained for full text article assessment. Forty papers met our inclusion criteria. Further, 25 papers reporting the investigation of efficacy of tocilizumab on COVID 19 were included in the qualitative analysis and finally eighteen studies were selected for the quantitative analysis (meta-analysis).

\subsection{Study characteristics}

The characteristics of the included studies are summarized in Table 1. There was a large variation in the characteristics of selected studies due to relatively short course of disease ( 7 to 35 days) and were considered to have not a satisfactory follow up duration. 14 studies were retrospective and 4 were prospective nonrandomized case series. Eighteen studies [9], [16], [24]-[33], [17], [34], [18]-[20], [20]-[23] that assessed mortality, 13 also reported clinical improvements in COVID 19 patients and 15 assessed the need for mechanical ventilation by the patients. Among countries where case series reported, USA-5, Italy-4, China-2, France-1, Qatar-1, India-1, Turkey-1, Japan-1 Spain=1 and Russia-1. Common co-morbidities reported in COVID 19 patients were hypertension, diabetes mellitus, chronic pulmonary disorder, obesity, rheumatoid arthritis and kidney disease. Only few studies treating COVID 19 patients with tocilizumab did not report any adverse events. The reported common events were $\uparrow$ hepatic enzymes, creatinine, hyperkalemia, serious bacterial and fungal infections, anemia, rise in ALT and QT interval prolongation. Majority of the studies adopted standard of care treatment (SOC) along with one to three doses of tocilizumab. The commonly employed drugs as part of SOC were amoxycillin and clavulanic acid combination, ceftriaxone, levofloxacillin, low molecular weight heparins, interferons, azithromycin. The standard 
medRxiv preprint doi: https://doi.org/10.1101/2020.08.12.20173682; this version posted August 15, 2020. The copyright holder for this preprint (which was not certified by peer review) is the author/funder, who has granted medRxiv a license to display the preprint in perpetuity.

It is made available under a CC-BY-ND 4.0 International license .

recommended regimen for tocilizumab is is 4 to $8 \mathrm{mg} / \mathrm{kg}$ to a maximum of $800 \mathrm{mg}$ per dose, with an additional dose 8 to 12 hours later if clinically required. All the included studies found to follow this regimen (Table 1).

\subsection{Quality assessment of the included studies}

Out of eighteen studies, 14 were retrospective ref and 4 studies were prospective nonrandomized case series. The quality of each study was assessed according to the Institute of Health Economics Quality Appraisal Checklist for Case Series Studies[11] is provided in Table 2. Overall scores based on the positive attributes in varied from 9to 18 out of a possible 20. The study conducted by Sciascia et al had the highest score, with 18 points, whereas study by Rand et al had a score of 17 . Studies by Andrew et al, Shoji et al and Betul Borku et al had a score of 16. Score for other studies ranged from 9 to 15. The overall lowest score (5) was for the questions, description of co-interventions and prospective type of study. Therefore, most studies were of poor to moderate quality according to the checklist.

\subsection{Meta-analysis}

A total of 25 articles were contributed to qualitative synthesis and 18 ( $n=1212$ patients) included for quantitative synthesis (meta-analysis) (Figure 1). Individual study characteristics including patient demographics, disease complications and tocilizumab dose and duration are presented in Table 1. The mortality rate of COVID-19 patients in the included case series treated with tocilizumab group was $21 \%$ (251/1212) with the pooled adjusted overall estimate 0.189 (95\% CI 0.137-0.253). Across studies, there was a large positive effect of tocilizumab in reducing mortality as indicated by the forest plot. Among the included studies, 4 studies reported zero deaths in tocilizumab treated patients (Figure 2). Forest plot analysis of the primary outcome, mortality (Figure 2) also shows substantial heterogeneity among the included studies $\left(\mathrm{I}^{2}=78.89 \%, \mathrm{p}<0.001\right)$. A visual assessment of the studies' results suggests between-study variability and the majority of individual study point estimates of the treatment effect are on the negative side of the line of overall effect but do not overlap, indicating a difference in treatment effect magnitude among studies. The confidence intervals for each study's treatment effect (horizontal lines) do not overlap one another, and the upper and lower limits of the CI consistently line up on vertical axis, indicating a treatment effect among studies near to overall proportion effect. 
medRxiv preprint doi: https://doi.org/10.1101/2020.08.12.20173682; this version posted August 15, 2020. The copyright holder for this preprint (which was not certified by peer review) is the author/funder, who has granted medRxiv a license to display the preprint in perpetuity.

It is made available under a CC-BY-ND 4.0 International license .

Figure 3 and 4 represent the forest plots of effect sizes (adjusted logit proportions) for the tocilizumab effect on clinical improvement and the need for the mechanical ventilation for the patients following treatment with tocilizumab respectively. Figure 3 shows the results for 13 studies that included the data for 721 COVID 19 patients that underwent treatment with tocilizumab. The overall estimate displays a positive effect of tocilizumab with nearly $61 \%$ of patients getting improved (overall estimate and $95 \%$ CI 0.621 [0.508,0.722]. Similarly, figure 4 shows the results for 15 studies that included the data for 1091 COVID 19 patients that underwent treatment with tocilizumab. The overall estimate displays a positive effect for tocilizumab with nearly $15 \%$ of patients only needed to be mechanically ventilated (overall estimate and 95\% CI 0.158 [0.107,0.227]. These forest plots, however, (Figure 3 and 4 ) also show substantial heterogeneity among the included studies $\left(\mathrm{I}^{2}=83.7 \%\right.$ and $81.3 \%$ respectively). A visual assessment of the studies' results in these plots suggests betweenstudy variability and more individual study point estimates of the treatment effect are on the positive side of the line of overall effect (figure 3) effect and conversely more on negative in figure 4 indicating an overall beneficial effect following treatment with tocilizumab.

\subsection{Assessment of publication bias of included studies}

Figure 5 represents a relationship between treatment effect and study precision giving an asymmetric funnel plot in the cylindrical form due to publication bias or differences between higher and lower precision studies (typically 'small study effects'). There was one study as an outlier falling outside of funnel. This asymmetry may also be arising due to use of an inappropriate effect measure warranting further investigation of possible causes.

\section{DISCUSSION}

Tocilizumab is a humanized monoclonal antibody capable of interfering with the IL-6 binding and activation. High levels of IL-6 have been implicated in cytokine storm, cytokine release syndrome (CRS) and hypercoagulable state which are responsible for potentially causing life-threatening multiorgan damage and high risk of deaths[35]-[40]. Evidence on efficacy and safety of tocilizumab for COVID-19 from the indirect preclinical data suggests rationale for using tocilizumab and observational studies suggest that treatment with tocilizumab may be associated with more favorable outcomes compared to standard care in patients with severe or critical COVID-19[6]. Until now no RCTs have been published or made available pre-print for the effectiveness and safety of tocilizumab in the context of COVID-19. Several observational studies have examined whether tocilizumab has 
medRxiv preprint doi: https://doi.org/10.1101/2020.08.12.20173682; this version posted August 15, 2020. The copyright holder for this preprint (which was not certified by peer review) is the author/funder, who has granted medRxiv a license to display the preprint in perpetuity.

It is made available under a CC-BY-ND 4.0 International license .

any effect in patients with COVID-19. Although many of the patients included in such studies had severe or critical disease and many were admitted to ICU. Drawing conclusions from such findings is a leap of faith, given that most had small sample sizes and high or moderate risk of bias.(37-40)

The assessment of quality of publications had score from 9 to 15 out of a possible 20 points indicating the studies to be of poor to moderate quality according to the "Quality Appraisal Checklist for Case Studies" tool developed by the Institute of Health Economics[11].

There was a large variation in the characteristics of selected studies and do not seem to have satisfactory follow up duration and majority of them were retrospective in nature. Eighteen studies assessed the mortality of COVID 19 patients following treatment with tocilizumab with an overall mortality rate $21 \%(251 / 1212)$ ). The other metanalysis carried to assess efficacy of tocilizumab in case controlled and cohort studies also reported similar mortality rate of $22.4 \%(258 / 1,153)$ when compared to control[6]. However it is noteworthy to mention there was a substantial heterogeneity $\left(\mathrm{I}^{2}=78.9 \%\right)$ in our study which is also similar to other published metanalysis $\left(\mathrm{I}^{2}=80 \%\right)$ [6]. The possible reasons for heterogeneity being, difference in the age, study design, treatment strategies, presence of comorbidities and variability in the follow-up period. About thirteen studies also reported clinical improvements in COVID 19 patients (436/721) and fifteen studies (158/1091) assessed the need for mechanical ventilation by the patients.[9], [16], [24]-[32], [17]-[20], [20]-[23] [9], [16], [25], [27], [29]-[31],[34], [17]-[24] Majority of the case series reported were found to from USA- and Italy. Common co-morbidities reported in COVID 19 patients were hypertension, diabetes mellitus, chronic pulmonary disorder, obesity, rheumatoid arthritis and kidney disease. Only few studies treating COVID 19 patients with tocilizumab did not report any adverse events. Majority of the studies adopted standard of care treatment (SOC) along with one to three doses of tocilizumab. The results generated in the current meta-analysis should be taken in context with the evidence available for the efficacy of tocilizumab in the treatment of COVID 19 infections in the best interest of tackling this pandemic. As case reports and case series are uncontrolled study designs with known risk of bias but should help us in this tiring time to advance our knowledge and preparedness.

In conclusion the present synthesis and inference derived from case reports and case series should provide us useful insights with the other available evidence to refine our strategy and equip ourselves effectively with tocilizumab to defeat COVID 19 to save humanity. We suggest using evidence derived from the metanalysis of the current case series to inform decision-making about the efficacy 
medRxiv preprint doi: https://doi.org/10.1101/2020.08.12.20173682; this version posted August 15, 2020. The copyright holder for this preprint (which was not certified by peer review) is the author/funder, who has granted medRxiv a license to display the preprint in perpetuity.

It is made available under a CC-BY-ND 4.0 International license .

of tocilizumab for COVID 19 until the higher level of evidence is available through randomized controlled trials.

\section{Limitations}

The included studies utilized varied doses of tocilizumab (single or double), and duration drug availability issues emerged in some centers, which may have influenced both sample sizes and study designs.

The treatment allocations in these observational studies were based solely upon physician judgement rather than random assignment thereby leading to chances of risk of bias without accounting for risk factors. As the case series consists of studies with low sample sizes might likely cause over estimation of the overall effect size.

\section{Clinical implications}

Incorporating studies without control groups into systematic reviews and quantitative synthesis especially when there are no other studies to consider can provide information for formulating effective treatment strategies for management of COVID 19 infections through the use of tocilizumab.

Clinicians should continue compassionate use of tocilizumab as an option for COVID-19 patients and enroll COVID-19 patients in clinical trials for assessing the safety and efficacy of tocilizumab until the future RCTs enlighten the clinical efficacy of tocilizumab.

\section{Declaration of Competing Interest}

The authors declare that there are no conflicts of interest regarding the publication of this article. 


\section{References}

[1] Worldometer, “Coronavirus Cases,” Worldometer, pp. 1-22, 2020, doi: 10.1101/2020.01.23.20018549V2.

[2] "Symptoms of Coronavirus | CDC.” [Online]. Available: https://www.cdc.gov/coronavirus/2019-ncov/symptoms-testing/symptoms.html. [Accessed: 11-Aug-2020].

[3] C. Chen, X. R. Zhang, Z. Y. Ju, and W. F. He, "[Advances in the research of mechanism and related immunotherapy on the cytokine storm induced by coronavirus disease 2019].," Zhonghua Shao Shang Za Zhi, vol. 36, no. 6, pp. 471-475, 2020, doi: 10.3760/cma.j.cn501120-20200224-00088.

[4] T.-Z. Song et al., "Delayed severe cytokine storm and immune cell infiltration in SARSCoV-2-infected aged Chinese rhesus macaques.," Zool. Res., pp. 1-10, Aug. 2020, doi: 10.24272/j.issn.2095-8137.2020.202.

[5] S. Khiali, E. Khani, and T. Entezari-Maleki, "A Comprehensive Review of Tocilizumab in COVID-19 Acute Respiratory Distress Syndrome,” J. Clin. Pharmacol., 2020, doi: 10.1002/jcph.1693.

[6] U. Boregowda, A. Perisetti, A. Nanjappa, M. Gajendran, and H. Goyal, Addition of Tocilizumab to the standard of care reduces mortality in severe COVID-19: A systematic review and meta-analysis. 2020.

[7] C. Campochiaro et al., "European Journal of Internal Medicine Original article E ffi cacy and safety of tocilizumab in severe COVID-19 patients : a single- centre retrospective cohort study," vol. 76, no. May, pp. 43-49, 2020.

[8] L. Wang, X. Peng, Z. H. Wang, J. Cai, and F. C. Zhou, "Tocilizumab in the treatment of a critical COVID-19 patient: A case report," Eur. Rev. Med. Pharmacol. Sci., vol. 24, no. 10, pp. 5783-5787, 2020, doi: 10.26355/eurrev_202005_21372.

[9] S. Hashimoto et al., "A retrospective study evaluating efficacy and safety of compassionate use of tocilizumab in 13 patients with severe-to-critically ill COVID-19: analysis of wellresponding cases and rapidly-worsening cases after tocilizumab administration," medRxiv, p. 
medRxiv preprint doi: https://doi.org/10.1101/2020.08.12.20173682; this version posted August 15, 2020. The copyright holder for this preprint (which was not certified by peer review) is the author/funder, who has granted medRxiv a license to display the preprint in perpetuity. It is made available under a CC-BY-ND 4.0 International license .

2020.06.24.20134288, 2020, doi: 10.1101/2020.06.24.20134288.

[10] N. Potere et al., "Interleukin-6 receptor blockade with subcutaneous tocilizumab in severe COVID-19 pneumonia and hyperinflammation: A case-control study," Ann. Rheum. Dis., vol. 0, no. 0, pp. 2-3, 2020, doi: 10.1136/annrheumdis-2020-218243.

[11] C. Moga, B. Guo, and C. Harstall, "Development of a Quality Appraisal Tool for Case Series Studies Using a Modified Delphi Technique,” IHE Publ., no. September, pp. 1-71, 2012.

[12] R. El Dib, P. Nascimento Junior, and A. Kapoor, "An alternative approach to deal with the absence of clinical trials. A proportional meta-analysis of case series studies," Acta Cir. Bras., vol. 28, no. 12, pp. 870-876, 2013, doi: 10.1590/S0102-86502013001200010.

[13] M. H. Murad, S. Sultan, S. Haffar, and F. Bazerbachi, "Methodological quality and synthesis of case series and case reports," Evid. Based. Med., vol. 23, no. 2, pp. 60-63, 2018, doi: 10.1136/bmjebm-2017-110853.

[14] M. J. Rousseau and J. C. Evans, "Key statistical assumptions and methods in one-arm metaanalyses with binary endpoints and low event rates, including a real-life example in the area of endoscopic colonic stenting," Cogent Med., vol. 4, no. 1, 2017, doi: 10.1080/2331205x.2017.1334318.

[15] N. Wang, "How to Conduct a Meta-Analysis of Proportions in R : A Comprehensive Tutorial Conducting Meta-Analyses of Proportions in R,” John Jay Coll. Crim. Justice, no. June, pp. 0-62, 2018, doi: 10.13140/RG.2.2.27199.00161.

[16] R. Marfella, P. Paolisso, C. Sardu, L. Bergamaschi, E. C. D. Angelo, and M. Barbieri, "Since January 2020 Elsevier has created a COVID-19 resource centre with free information in English and Mandarin on the novel coronavirus COVID- 19. The COVID-19 resource centre is hosted on Elsevier Connect, the company' s public news and information ," no. January, 2020.

[17] X. Xu et al., "Effective treatment of severe COVID-19 patients with tocilizumab," Proc. Natl. Acad. Sci. U. S. A., vol. 117, no. 20, pp. 10970-10975, 2020, doi: 10.1073/pnas.2005615117.

[18] B. Borku Uysal et al., "Tocilizumab challenge: A series of cytokine storm therapy 
medRxiv preprint doi: https://doi.org/10.1101/2020.08.12.20173682; this version posted August 15, 2020. The copyright holder for this preprint (which was not certified by peer review) is the author/funder, who has granted medRxiv a license to display the preprint in perpetuity. It is made available under a CC-BY-ND 4.0 International license.

experiences in hospitalized COVID-19 pneumonia patients," J. Med. Virol., pp. 0-1, 2020, doi: 10.1002/jmv.26111.

[19] R. Alattar et al., "Tocilizumab for the treatment of severe coronavirus disease 2019," J. Med. Virol., 2020, doi: 10.1002/jmv.25964.

[20] C. A. Rimland et al., "Clinical characteristics and early outcomes in patients with COVID-19 treated with tocilizumab at a United States academic center," medRxiv, p.

2020.05.13.20100404, Jun. 2020, doi: 10.1101/2020.05.13.20100404.

[21] D. S. Formina et al., "Temporal clinical and laboratory response to interleukin-6 receptor blockade with Tocilizumab in 89 hospitalized patients with COVID-19 pneumonia," medRxiv, vol. 2, p. 2020.06.12.20122374, Jun. 2020, doi: 10.1101/2020.06.12.20122374.

[22] S. Sciascia et al., "Pilot prospective open, single-arm multicentre study on off-label use of tocilizumab in patients with severe COVID-19," Clin. Exp. Rheumatol., vol. 38, no. 3, pp. 529-532, 2020.

[23] A. Ip et al., "Hydroxychloroquine and Tocilizumab Therapy in COVID-19 Patients - An Observational Study," medRxiv, p. 2020.05.21.20109207, May 2020, doi:

10.1101/2020.05.21.20109207.

[24] C. C. Price et al., "Tocilizumab Treatment for Cytokine Release Syndrome in Hospitalized COVID-19 Patients," Chest, vol. 5, no. June, pp. 1-12, 2020, doi:

10.1016/j.chest.2020.06.006.

[25] T. Conrozier et al., "Biomarker variation in patients successfully treated with tocilizumab for severe coronavirus disease 2019 (COVID-19): results of a multidisciplinary collaboration.," Clin. Exp. Rheumatol., vol. 2019, no. June, 2020.

[26] V. Morena et al., "Off-label use of tocilizumab for the treatment of SARS-CoV-2 pneumonia in Milan, Italy," Eur. J. Intern. Med., vol. 76, no. April, pp. 36-42, 2020, doi: 10.1016/j.ejim.2020.05.011.

[27] P. Luo, Y. Liu, L. Qiu, X. Liu, D. Liu, and J. Li, “Tocilizumab treatment in COVID-19: A single center experience," J. Med. Virol., vol. 92, no. 7, pp. 814-818, 2020, doi: 10.1002/jmv.25801. 
medRxiv preprint doi: https://doi.org/10.1101/2020.08.12.20173682; this version posted August 15, 2020. The copyright holder for this preprint (which was not certified by peer review) is the author/funder, who has granted medRxiv a license to display the preprint in perpetuity. It is made available under a CC-BY-ND 4.0 International license .

[28] A. Patel et al., "Safety and efficacy of tocilizumab in the treatment of severe acute respiratory syndrome coronavirus-2 pneumonia: A retrospective cohort study," Indian J. Med.Microbiol., vol. 38, no. 1, p. 117, 2020,doi: 10.4103/ijmm.ijmm_20_298.

[29] J. P. Knorr, V. Colomy, C. M. Mauriello, and S. Ha, “Tocilizumab in patients with severe COVID-19: A single-center observational analysis," J. Med. Virol., pp. 0-1, 2020, doi: 10.1002/jmv.26191.

[30] P. Toniati et al., "Since January 2020 Elsevier has created a COVID-19 resource centre with free information in English and Mandarin on the novel coronavirus COVID- 19. The COVID-19 resource centre is hosted on Elsevier Connect, the company's public news and information," no. January, 2020.

[31] M. Gorgolas et al., "Compassionate Use of Tocilizumab in Severe SARS-CoV2 Pneumonia When late administration is too late," medRxiv, p. 2020.06.13.20130088, Jun. 2020, doi: 10.1101/2020.06.13.20130088.

[32] R. Petrak et al., "Tocilizumab as a Therapeutic Agent for Critically Ill Patients Infected with SARS-CoV-2," medRxiv, p. 2020.06.05.20122622, Jun. 2020, doi:

10.1101/2020.06.05.20122622.

[33] R. Alattar et al., "Tocilizumab for the treatment of severe coronavirus disease 2019," J. Med. Virol., p. jmv.25964, May 2020, doi: 10.1002/jmv.25964.

[35] B. Liu, M. Li, Z. Zhou, X. Guan, and Y. Xiang, "Since January 2020 Elsevier has created a COVID-19 resource centre with free information in English and Mandarin on the novel coronavirus COVID- 19. The COVID-19 resource centre is hosted on Elsevier Connect, the company' s public news and information ," no. January, 2020.

[36] M. Zhao, "Since January 2020 Elsevier has created a COVID-19 resource centre with free information in English and Mandarin on the novel coronavirus COVID- 19 . The COVID-19 resource centre is hosted on Elsevier Connect, the company's public news and information ," no. January, 2020.

[37] B. Hu, S. Huang, and L. Yin, “The cytokine storm and COVID-19," J. Med. Virol., vol. 2, 
medRxiv preprint doi: https://doi.org/10.1101/2020.08.12.20173682; this version posted August 15, 2020. The copyright holder for this preprint (which was not certified by peer review) is the author/funder, who has granted medRxiv a license to display the preprint in perpetuity.

It is made available under a CC-BY-ND 4.0 International license .

pp. 0-2, 2020, doi: 10.1002/jmv.26232.

[38] J. Stebbing et al., "COVID-19: combining antiviral and anti-inflammatory treatments," Lancet Infect. Dis., vol. 20, no. 4, pp. 400-402, 2020, doi: 10.1016/S1473-3099(20)30132-8.

[39] C. Zhang, Z. Wu, J. Li, H. Zhao, and G. Wang, "Cytokine release syndrome in severe COVID-19: interleukin-6 receptor antagonist," no. January, 2020.

[40] C. Chakraborty, A. R. Sharma, M. Bhattacharya, G. Sharma, S. S. Lee, and G. Agoramoorthy, "COVID-19: Consider IL-6 receptor antagonist for the therapy of cytokine storm syndrome in SARS-CoV-2 infected patients," J. Med. Virol., pp. 0-2, 2020, doi: 10.1002/jmv.26078.

[41] M. Melody et al., "Case report: use of lenzilumab and tocilizumab for the treatment of coronavirus disease 2019," Immunotherapy, 2020, doi: 10.2217/imt-2020-0136.

[42] M. V Sheianov, Y. D. Udalov, S. S. Ochkin, A. N. Bashkov, and A. S. Samoilov, "Pulse Therapy With Corticosteroids and Intravenous Immunoglobulin in the Management of Severe Tocilizumab-Resistant COVID-19: A Report of Three Clinical Cases.," Cureus, vol. 12, no. 7, p. e9038, 2020, doi: 10.7759/cureus.9038.

[43] C. A. Rimland et al., "Clinical characteristics and early outcomes in patients with COVID-19 treated with tocilizumab at a United States academic center," medRxiv, p. 2020.05.13.20100404, 2020, doi: 10.1101/2020.05.13.20100404.

[44] A. Chaidos, A. Katsarou, C. Mustafa, D. Milojkovic, and A. Karadimitris, "Interleukin 6blockade treatment for severe COVID-19 in two patients with multiple myeloma," $\mathrm{Br} . J$. Haematol., vol. 190, no. 1, pp. e9-e11, 2020, doi: 10.1111/bjh.16787. 
Table 1 Case series examining the effect of Tocilizumab COVID 19 patients

\begin{tabular}{|c|c|c|c|c|c|c|c|c|c|c|}
\hline S.No & $\begin{array}{l}\text { Author, } \\
\text { year }\end{array}$ & Country & $\begin{array}{l}\text { Type of } \\
\text { study }^{\#}\end{array}$ & $\begin{array}{l}\text { Populat } \\
\text { ion (n) }\end{array}$ & $\begin{array}{l}\text { Age in yrs } \\
\text { Mean } \\
\text { (range) }\end{array}$ & $\begin{array}{l}\text { Male } \\
\text { (n) }\end{array}$ & $\begin{array}{l}\text { Common } \\
\text { comorbidities }^{\#}\end{array}$ & $\begin{array}{l}\text { TCZ doses, } \\
\text { duration }\end{array}$ & $\begin{array}{l}\text { Standard of care } \\
\#\end{array}$ & $\begin{array}{l}\text { Adverse } \\
\text { events }\end{array}$ \\
\hline 1 & Conrozie & France & $\mathbf{R}$ & 40 & $\begin{array}{l}73.7 \quad(65- \\
89)\end{array}$ & & $\begin{array}{l}\text { HT, DM, } \\
\text { COPD or } \\
\text { emphysema }\end{array}$ & $\begin{array}{l}\text { 8mg/kg/da } \\
\text { y, IV }\end{array}$ & $\begin{array}{l}\text { Amoxiclav/ceft/l } \\
\text { ev/LMWH }\end{array}$ & NR \\
\hline 2 & Marfella & Italy & $\mathbf{R}$ & 78 & NR & & DM & $\begin{array}{l}8 \mathrm{mg} / \mathrm{kg} / 12 \\
\mathrm{~h}, \mathrm{IV}, \text { two } \\
\text { doses }\end{array}$ & NR & NR \\
\hline 3 & Patel & India & $\mathbf{R}$ & 20 & $54(47-63)$ & 17 & DM, HT, IHD & $\begin{array}{l}8 \mathrm{mg} / \mathrm{kg} / 12 \\
\mathrm{~h}, \mathrm{IV}, \text { two } \\
\text { doses }\end{array}$ & $\begin{array}{l}\text { HCQ/AZT/ceft/ } \\
\text { LMWH }\end{array}$ & \\
\hline 4 & $\begin{array}{l}\text { Betul } \\
\text { Borku }\end{array}$ & Turkey & $\mathbf{P}$ & 12 & $\begin{array}{l}65.83(47- \\
69)\end{array}$ & 6 & $\begin{array}{l}\text { DM, HT, } \\
\text { COPD, } \\
\text { malignancy, } \\
\text { chronic renal } \\
\text { failure }\end{array}$ & $\begin{array}{l}\text { IV } 400 \mathrm{mg} \text {, } \\
\text { two doses } \\
\text { in } 24 \mathrm{hrs}\end{array}$ & $\begin{array}{l}\text { HCQ/AZT/oselt } \\
\text { amivir/moxiflox } \\
\text { acin }\end{array}$ & NR \\
\hline
\end{tabular}




\begin{tabular}{|c|c|c|c|c|c|c|c|c|c|c|}
\hline 5 & Paola, & Italy & $\mathbf{P}$ & 100 & $\begin{array}{l}62 \\
(57-71)\end{array}$ & 88 & $\begin{array}{l}\text { DM, } \\
\text { cardiovascula } \\
\text { r disease, } \\
\text { COPD, } \\
\text { chronic renal } \\
\text { failure }\end{array}$ & $\begin{array}{l}8 \mathrm{mg} / \mathrm{kg} / 12 \\
\mathrm{~h}, \mathrm{IV}, \text { two } \\
\text { doses }\end{array}$ & NR & NR \\
\hline 6 & $\begin{array}{l}\text { John } \\
\text { Knorr }\end{array}$ & USA & $\mathbf{R}$ & 66 & age $\geq 18$ & & $\begin{array}{lr}\text { DM, } & \text { HT, } \\
\text { asthma } & \text { or } \\
\text { COPD } & \end{array}$ & $\begin{array}{l}\text { 8mg/kg, } 3 \\
\text { doses/24hr } \\
\mathrm{s}\end{array}$ & HCQ & NR \\
\hline 7 & Pan Luo & china & $\mathbf{R}$ & 15 & $73(62-80)$ & 12 & $\begin{array}{l}\text { CVD and } \\
\text { endocrine } \\
\text { diseases }\end{array}$ & 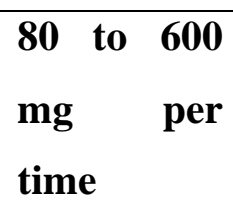 & Gluco & NR \\
\hline 8 & $\begin{array}{l}\text { Xiaoling } \\
\text { Xua }\end{array}$ & china & $\mathbf{R}$ & 21 & $\begin{array}{ll}56.8 & (25- \\
88) & \end{array}$ & & $\begin{array}{l}\text { HT, } \quad \text { DM, } \\
\text { COPD, CHD }\end{array}$ & $\begin{array}{l}\text { 8mg/kg, } \\
\text { two } \\
\text { doses/24hr } \\
\text { s }\end{array}$ & $\begin{array}{l}\text { Lopinavir/riton } \\
\text { avir//IFN }\end{array}$ & NR \\
\hline 9 & Christina & USA & $\mathbf{R}$ & 153 & $64(22-99)$ & 125 & $\begin{array}{l}\text { DM, } \\
\text { immunosuppr } \\
\text { essed, COPD, } \\
\text { obesity }\end{array}$ & $\begin{array}{l}\mathrm{mg} / \mathrm{kg}, \\
\text { two } \\
\text { doses/24hr } \\
\text { s }\end{array}$ & $\begin{array}{l}\text { HCQ/Gluco/anti } \\
\text { virals }\end{array}$ & NR \\
\hline
\end{tabular}




\begin{tabular}{|c|c|c|c|c|c|c|c|c|c|c|}
\hline 10 & Andrew & USA & $\mathbf{R}$ & 134 & \begin{tabular}{|lll}
62 & $(53$ & - \\
$70)$ & & \\
\end{tabular} & 99 & $\begin{array}{l}\text { DM, COPD, } \\
\text { HT, Renal } \\
\text { failure, obesity }\end{array}$ & $\begin{array}{l}400 \mathrm{mg}, \\
\text { single dose }\end{array}$ & None & NR \\
\hline 11 & $\begin{array}{l}\text { Shoji } \\
\text { Hashimoto }\end{array}$ & JAPAN & $\mathbf{R}$ & 13 & $61.6 \pm 14.7$ & 11 & $\begin{array}{l}\text { DM, HT, } \\
\text { COPD, } \\
\text { Dyslipidemia, } \\
\text { RA }\end{array}$ & $\begin{array}{l}400 \mathrm{mg}, \\
\text { single dose }\end{array}$ & $\begin{array}{l}\text { Ciclesonide/Favi } \\
\text { piravir/ } \\
\text { Methylprednisol } \\
\text { one }\end{array}$ & NR \\
\hline 12 & $\begin{array}{l}\text { Rand } \\
\text { Alattar }\end{array}$ & Qatar & $\mathbf{R}$ & 25 & $58(50-63)$ & 23 & $\begin{array}{l}\text { DM, chronic } \\
\text { kidney } \\
\text { disease, and } \\
\text { CVD }\end{array}$ & \begin{tabular}{|lr}
\multicolumn{2}{|l|}{ median } \\
total & dose \\
of & 5.7 \\
$\mathrm{mg} / \mathrm{kg}$ & \\
\end{tabular} & $\begin{array}{l}\text { HCQ/AZT/lopin } \\
\text { avir/ritonavir/I } \\
\text { NT }\end{array}$ & $\begin{array}{l}\text { Anemia, } \\
\text { rise in } \\
\text { ALT and } \\
\text { QT } \\
\text { interval } \\
\text { prolongati } \\
\text { on }\end{array}$ \\
\hline 13 & Sciascia & ITALY & $\mathbf{P}$ & 63 & $62.6 \pm 12.5$ & 56 & $\begin{array}{l}\text { DM, chronic } \\
\text { kidney } \\
\text { disease, and } \\
\text { CVD }\end{array}$ & $\begin{array}{l}8 \mathrm{mg} / \mathrm{kg}, \mathrm{IV} \\
\text { two doses }\end{array}$ & $\begin{array}{l}\text { Lopinavir/riton } \\
\text { avir/ } \\
\text { Darunavir/cobic } \\
\text { istat }\end{array}$ & NR \\
\hline
\end{tabular}




\begin{tabular}{|c|c|c|c|c|c|c|c|c|c|c|}
\hline 14 & Valentina & ITALY & $\mathbf{P}$ & 51 & $60(50-70)$ & 40 & $\begin{array}{l}\text { CVD, HT, } \\
\text { DM, } \\
\text { Chronic lung } \\
\text { diseases, } \\
\text { Cancer, RA }\end{array}$ & $\begin{array}{l}8 \mathrm{mg} / \mathrm{kg}, \mathrm{IV} \\
\text { two doses }\end{array}$ & NR & $\begin{array}{l}\uparrow \quad \text { hepatic } \\
\text { enzymes, } \\
\text { thrombocy } \\
\text { topenia, } \\
\text { and } \\
\text { serious } \\
\text { bacterial } \\
\text { and fungal } \\
\text { infections }\end{array}$ \\
\hline 15 & Russell & USA & $\mathbf{R}$ & 145 & 58.1 & 93 & $\begin{array}{l}\text { DM, COPD, } \\
\text { chronic } \\
\text { cardiac or } \\
\text { renal disease, } \\
\text { immunodefici } \\
\text { ency }\end{array}$ & $\begin{array}{l}8 \mathrm{mg} / \mathrm{kg}, \text { IV } \\
\text { ONE TO } \\
\text { two } \\
\text { doses/24 h }\end{array}$ & NR & NONE \\
\hline 16 & Miguel & SPAIN & $\mathbf{R}$ & 186 & 65 & 126 & $\begin{array}{l}\text { DM, COPD, } \\
\text { Vasculopathy, } \\
\text { Immunosuppr } \\
\text { ession }\end{array}$ & & $\begin{array}{l}\text { Lopinavir/riton } \\
\text { avir/HCQ/DOX/ } \\
\text { AZT/LMWH }\end{array}$ & $\begin{array}{l}\uparrow \text { hepatic } \\
\text { enzymes, } \\
\text { creatinine, } \\
\text { hyperkale } \\
\text { mia }\end{array}$ \\
\hline
\end{tabular}




\begin{tabular}{|l|l|l|l|l|l|l|l|l|l|l|}
\hline 17 & Daria & RUSSIA & R & 89 & 53 & & DM, COPD, & & NR \\
\hline 18 & & USA & R & & 59 & 9 & HT, DM, & 8 mg/kg, IV & NR \\
& $\begin{array}{l}\text { Casey A. } \\
\text { Rimland }\end{array}$ & & 11 & $(48-65)$ & & $\begin{array}{l}\text { One to two } \\
\text { diseases, } \\
\text { Obesity }\end{array}$ & doses/24 h & \\
\hline
\end{tabular}

Abbreviations used in the table above, R: retrospective study, P: retrospective study, NR: Not Reported, HT: hypertension, DM: diabetes mellitus, COPD: chronic pulmonary disorder, Amoxiclav: amoxycillin and clavulanic acid combination, ceft: ceftriaxone, lev: levofloxacillin, LMWH: low molecular weight heparins, INF: interferons, AZT: azithromycin, ALT: alanine aminotransferase, RA: rheumatoid arthritis 
Table 2: Quality assessment of the included studies as per Institute of Health Economics (IHE) checklist

\begin{tabular}{|c|c|c|c|c|c|c|c|c|c|c|c|c|c|c|c|c|c|c|c|c|}
\hline $\begin{array}{l}\text { S. } \\
\text { No }\end{array}$ & Study References & 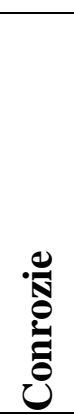 & 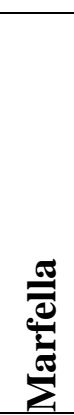 & 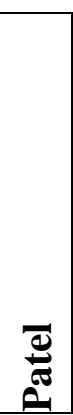 & 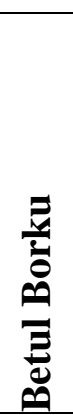 & 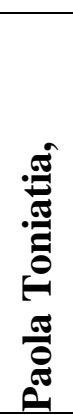 & 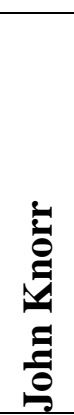 & $\stackrel{\varrho}{\stackrel{\Xi}{\varrho}}$ & 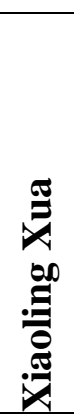 & 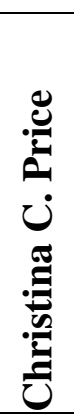 & $\frac{\hat{2}}{2}$ & $: \frac{1}{\mathscr{2}}$ & $\underset{\mathscr{E}}{\mathscr{E}}$ & 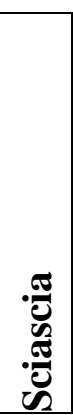 & 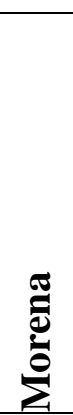 & $\stackrel{1}{\frac{1}{\pi}}$ & 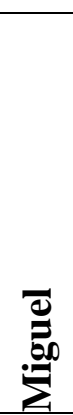 & 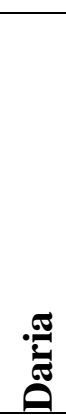 & 悹 & 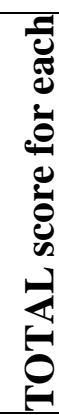 \\
\hline \multicolumn{21}{|c|}{ Study objective } \\
\hline 1 & $\begin{array}{l}\text { Was the hypothesis/aim/objective of } \\
\text { the study clearly stated? }\end{array}$ & $\sqrt{ }$ & $\mathbf{X}$ & $\sqrt{ }$ & $\sqrt{ }$ & $\sqrt{ }$ & $\sqrt{ }$ & $\sqrt{ }$ & $\sqrt{ }$ & $\sqrt{ }$ & $\sqrt{ }$ & $\sqrt{ }$ & $\sqrt{ }$ & $\sqrt{ }$ & $\sqrt{ }$ & $\sqrt{ }$ & $\sqrt{ }$ & $\mathbf{X}$ & $\sqrt{ }$ & 16 \\
\hline \multicolumn{21}{|c|}{ Study design } \\
\hline 2 & $\begin{array}{l}\text { Was the study conducted } \\
\text { prospectively? }\end{array}$ & $\mathbf{X}$ & $\sqrt{ }$ & $\mathbf{X}$ & $\sqrt{ }$ & $\sqrt{ }$ & $\mathbf{X}$ & $\mathbf{X}$ & $\mathbf{X}$ & $\mathbf{X}$ & $\mathbf{X}$ & $\mathbf{x}$ & $\mathbf{X}$ & $\sqrt{ }$ & $\sqrt{ }$ & $\mathbf{X}$ & $\mathbf{X}$ & $\mathbf{X}$ & $\mathbf{X}$ & 5 \\
\hline 3 & $\begin{array}{l}\text { Were the cases collected in more than } \\
\text { one centre? }\end{array}$ & $\mathbf{X}$ & $\mathbf{X}$ & $\mathbf{X}$ & $\mathbf{X}$ & $\sqrt{ }$ & $\mathbf{X}$ & $\mathbf{X}$ & $\sqrt{ }$ & $\sqrt{ }$ & $\sqrt{ }$ & $\mathbf{X}$ & $\mathbf{X}$ & $\sqrt{ }$ & $\mathbf{X}$ & $\sqrt{ }$ & $\mathbf{X}$ & $\mathbf{X}$ & $\sqrt{ }$ & 7 \\
\hline 4 & $\begin{array}{l}\text { Were patients } \\
\text { consecutively? }\end{array}$ & $\sqrt{ }$ & $\sqrt{ }$ & $\mathbf{X}$ & $\sqrt{ }$ & $\sqrt{ }$ & $\sqrt{ }$ & $\sqrt{ }$ & $\sqrt{ }$ & $\sqrt{ }$ & $\sqrt{ }$ & $\sqrt{ }$ & $\sqrt{ }$ & $\sqrt{ }$ & $\sqrt{ }$ & $\sqrt{ }$ & $\sqrt{ }$ & $\sqrt{ }$ & $\sqrt{ }$ & 17 \\
\hline & opulation & & & & & & & & & & & & & & & & & & & \\
\hline
\end{tabular}




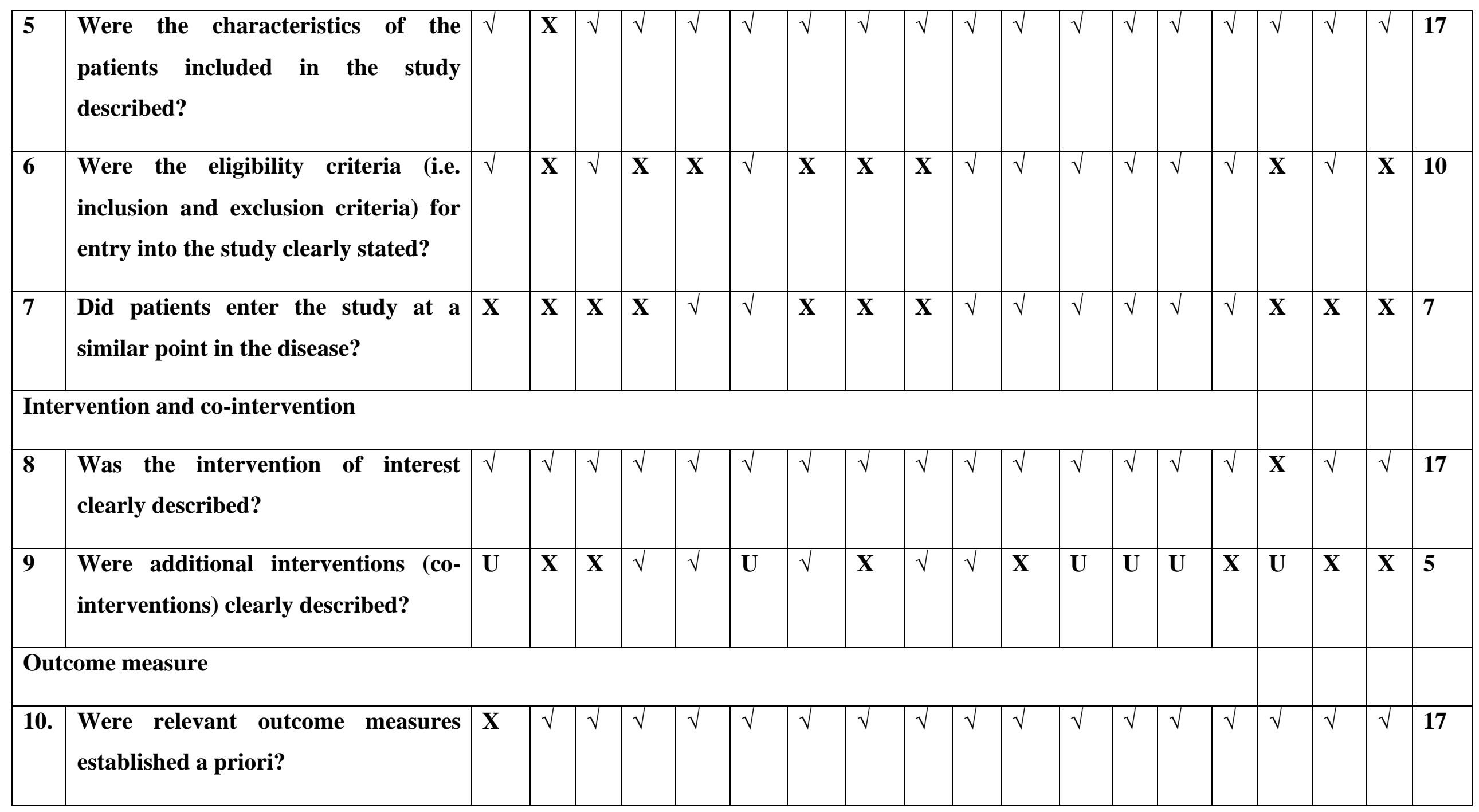




\begin{tabular}{|c|c|c|c|c|c|c|c|c|c|c|c|c|c|c|c|c|c|c|c|c|}
\hline 11. & $\begin{array}{l}\text { Were outcome assessors blinded to } \\
\text { the intervention that patients } \\
\text { received? }\end{array}$ & $\mathbf{U}$ & $\mathbf{X}$ & $\mathbf{U}$ & $\mathbf{U}$ & $\mathbf{U}$ & $\mathbf{U}$ & $\mathbf{X}$ & $\mathbf{U}$ & $\mathbf{X}$ & $\mathbf{X}$ & $\sqrt{ }$ & $\sqrt{ }$ & $\sqrt{ }$ & $\mathbf{X}$ & $\mathbf{X}$ & $\mathbf{X}$ & $\mathbf{X}$ & $\mathbf{X}$ & 3 \\
\hline 12. & $\begin{array}{l}\text { Were the relevant outcomes } \\
\text { measured using appropriate } \\
\text { objective/subjective methods? }\end{array}$ & $\sqrt{ }$ & $\sqrt{ }$ & $\sqrt{ }$ & $\sqrt{ }$ & $\sqrt{ }$ & $\sqrt{ }$ & $\sqrt{ }$ & $\sqrt{ }$ & $\sqrt{ }$ & $\sqrt{ }$ & $\sqrt{ }$ & $\sqrt{ }$ & $\sqrt{ }$ & $\sqrt{ }$ & $\sqrt{ }$ & $\sqrt{ }$ & $\sqrt{ }$ & $\mathbf{X}$ & 17 \\
\hline 13 & $\begin{array}{l}\text { Were the relevant outcome measures } \\
\text { made before and after the } \\
\text { intervention? }\end{array}$ & $\mathbf{X}$ & $\sqrt{ }$ & $\sqrt{ }$ & $\sqrt{ }$ & $\sqrt{ }$ & $\sqrt{ }$ & $\sqrt{ }$ & $\sqrt{ }$ & $\sqrt{ }$ & $\sqrt{ }$ & $\sqrt{ }$ & $\sqrt{ }$ & $\sqrt{ }$ & $\sqrt{ }$ & $\sqrt{ }$ & $\sqrt{ }$ & $\sqrt{ }$ & $\sqrt{ }$ & 17 \\
\hline \multicolumn{21}{|c|}{ Statistical analysis } \\
\hline 14 & $\begin{array}{l}\text { Were the statistical tests used to assess } \\
\text { the relevant outcomes appropriate? }\end{array}$ & $\sqrt{ }$ & $\sqrt{ }$ & $\sqrt{ }$ & $\sqrt{ }$ & $\mathbf{X}$ & $\sqrt{ }$ & $\sqrt{ }$ & $\sqrt{ }$ & $\sqrt{ }$ & $\sqrt{ }$ & $\sqrt{ }$ & $\sqrt{ }$ & $\sqrt{ }$ & $\sqrt{ }$ & $\sqrt{ }$ & $\sqrt{ }$ & $\sqrt{ }$ & $\sqrt{ }$ & 17 \\
\hline \multicolumn{21}{|c|}{ Results and conclusions } \\
\hline 15 & $\begin{array}{l}\text { Was follow-up long enough for } \\
\text { important events and outcomes to } \\
\text { occur? }\end{array}$ & $\mathbf{X}$ & $\mathbf{X}$ & $\mathbf{X}$ & $\sqrt{ }$ & $\sqrt{ }$ & $\sqrt{ }$ & $\sqrt{ }$ & $\sqrt{ }$ & $\mathbf{X}$ & $\sqrt{ }$ & $\mathbf{X}$ & $\sqrt{ }$ & $\sqrt{ }$ & $\sqrt{ }$ & $\mathbf{X}$ & $\sqrt{ }$ & $\mathbf{X}$ & $\mathbf{X}$ & $\mathbf{1 0}$ \\
\hline 16 & Were losses to follow-up reported? & $\mathbf{X}$ & $\mathbf{X}$ & $\mathbf{X}$ & $\sqrt{ }$ & $\mathbf{X}$ & $\mathbf{X}$ & $\mathbf{X}$ & $\mathbf{X}$ & $\sqrt{ }$ & $\sqrt{ }$ & $\mathbf{X}$ & $\sqrt{ }$ & $\sqrt{ }$ & $\mathbf{X}$ & $\mathbf{X}$ & $\sqrt{ }$ & $\mathbf{X}$ & $\sqrt{ }$ & 7 \\
\hline
\end{tabular}




\begin{tabular}{|c|c|c|c|c|c|c|c|c|c|c|c|c|c|c|c|c|c|c|c|c|}
\hline 17 & $\begin{array}{l}\text { Did the study provided estimates of } \\
\text { random variability in the data } \\
\text { analysis of relevant outcomes? }\end{array}$ & $\mathbf{X}$ & $\mathbf{X}$ & $\mathbf{X}$ & $\sqrt{ }$ & $\mathbf{X}$ & $\mathbf{X}$ & $\mathbf{X}$ & $\mathbf{X}$ & $\mathbf{X}$ & $\sqrt{ }$ & $\mathbf{X}$ & $\sqrt{ }$ & $\sqrt{ }$ & $\mathbf{X}$ & $\sqrt{ }$ & $\sqrt{ }$ & $\mathbf{X}$ & $\mathbf{X}$ & 6 \\
\hline 18 & Were the adverse events reported? & $\mathbf{X}$ & $\mathbf{X}$ & $\mathbf{X}$ & $\sqrt{ }$ & $\sqrt{ }$ & $\mathbf{X}$ & $\sqrt{ }$ & $\sqrt{ }$ & $\mathbf{X}$ & $\sqrt{ }$ & $\sqrt{ }$ & $\sqrt{ }$ & $\sqrt{ }$ & $\sqrt{ }$ & $\sqrt{ }$ & $\sqrt{ }$ & $\mathbf{X}$ & $\sqrt{ }$ & 12 \\
\hline 19 & $\begin{array}{l}\text { Were the conclusions of the study } \\
\text { supported by results? }\end{array}$ & $\sqrt{ }$ & $\sqrt{ }$ & $\sqrt{ }$ & $\sqrt{ }$ & $\sqrt{ }$ & $\sqrt{ }$ & $\sqrt{ }$ & $\sqrt{ }$ & $\sqrt{ }$ & $\sqrt{ }$ & $\sqrt{ }$ & $\sqrt{ }$ & $\sqrt{ }$ & $\sqrt{ }$ & $\sqrt{ }$ & $\sqrt{ }$ & $\sqrt{ }$ & $\sqrt{ }$ & 18 \\
\hline \multicolumn{21}{|c|}{ Competing interests and sources of support } \\
\hline 20 & $\begin{array}{l}\text { Were both competing interests and } \\
\text { sources of support for the study } \\
\text { reported? }\end{array}$ & $\sqrt{ }$ & $\mathbf{X}$ & $\mathbf{X}$ & $\mathbf{X}$ & $\mathbf{X}$ & $\sqrt{ }$ & $\sqrt{ }$ & $\mathbf{X}$ & $\mathbf{X}$ & $\mathbf{X}$ & $\mathbf{X}$ & $\mathbf{x}$ & $\mathbf{X}$ & $\sqrt{ }$ & $\mathbf{X}$ & $\sqrt{ }$ & $\mathbf{X}$ & $\sqrt{ }$ & 6 \\
\hline \multicolumn{2}{|c|}{ Total score per study } & 10 & 9 & 10 & 16 & 15 & 14 & 13 & 13 & 12 & 16 & 16 & 17 & 18 & 15 & 15 & 14 & 10 & 13 & \\
\hline
\end{tabular}

$\sqrt{ }=$ fulfilling the criterion, $X=$ not fulfilling the criterion, $U=U n c l e a r$ about fulfilling the criteria of the checklist. 
Figure 1. Flow chart of study selection process. The number of studies in each phase is indicated between brackets

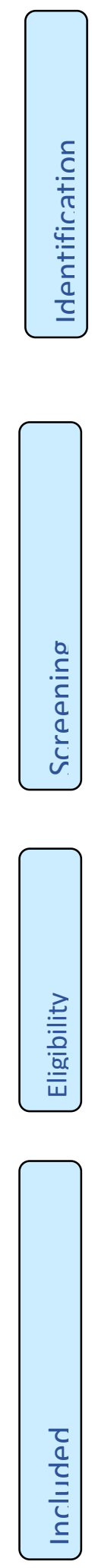

$$
\begin{aligned}
& \text { Records identified through } \\
& \text { searching of databases: PubMed } \\
& (n=258) \text { and Google ( } n=275), \\
& \text { preprints ( } n=20) \\
& \text { No restriction on language and } \\
& \text { year of publication }
\end{aligned}
$$

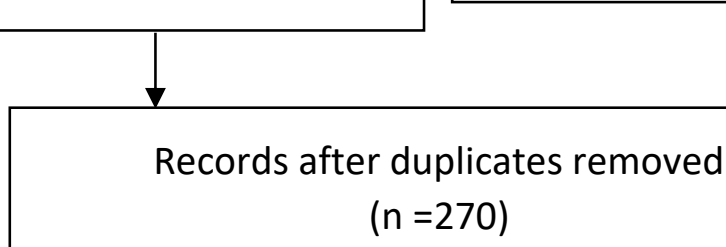

Additional records identified through other sources

$$
\text { ( } n=20)
$$

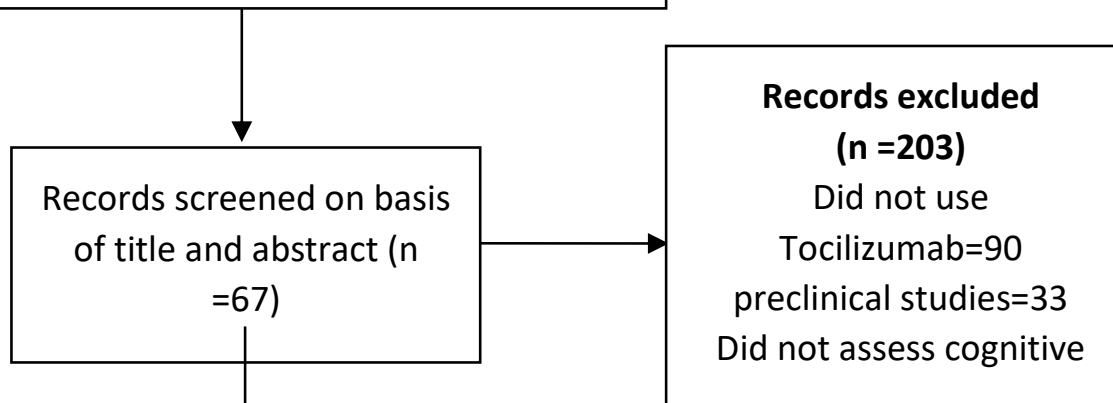

Full-text articles excluded with reasons

$$
(n=12)
$$

Full-text articles assessed for eligibility

$$
(n=40)
$$

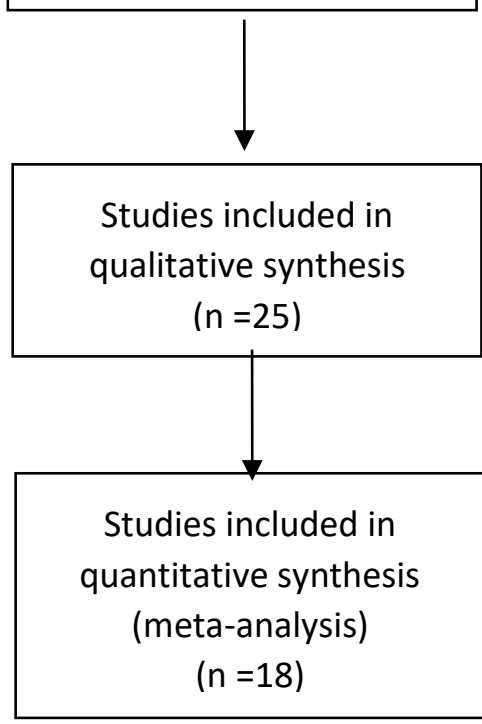

Not relevant review articles $=11$ invitro studies $=1$ id not use

\begin{tabular}{|c|c|}
\hline $\begin{array}{c}\text { Full-text articles assessed } \\
\text { for eligibility } \\
(\mathrm{n}=40)\end{array}$ & $\begin{array}{c}\text { Full-text articles excluded } \\
\text { with reasons } \\
(\mathrm{n}=12)\end{array}$ \\
& $\begin{array}{c}\text { Not relevant review } \\
\text { articles=11 } \\
\text { invitro studies }=1\end{array}$ \\
\hline
\end{tabular}

Studies included in qualitative synthesis

\begin{tabular}{c}
$\begin{array}{c}\text { Full-text articles excluded } \\
(\mathrm{n}=15) \\
\text { Inadequate data }=5 \\
\text { Insufficient cases }=10\end{array}$ \\
\hline
\end{tabular}

quantitative synthesis

(meta-analysis)

( $n=18$ ) 
medRxiv preprint doi: https://doi.org/10.1101/2020.08.12.20173682; this version posted August 15, 2020. The copyright holder for this preprint (which was not certified by peer review) is the author/funder, who has granted medRxiv a license to display the preprint in perpetuity.

It is made available under a CC-BY-ND 4.0 International license .

Figure 2 Forest plot of effect of tocilizumab on reduction in mortality of COVID 19 patients following treatment

Rrandom effects, $95 \%$ confidence interval

Studies

Conrozie 2020

R. Marfella 2020

Patel A, 2020

Paola Toniatia, 2020

John Knorr 2020

Pan Luo 2020

Xiaoling Xua 2020

Christina C. Price 2020

Andrew Ip, 2020

Shoji Hashimoto1 2020

Rand Alattar1 2020

S. Sciascia 2020

Valentina Morenab 2020

Russell M. Petrak 2020

Miguel Górgolas 2020

Daria S. Fomina 2020

Casey A. Rimland 2020
Betul Borku Uysal 2020

.

Estimate, 95\% CI Events/Total

$0.016(0.001,0.211)$

$0.006(0.000,0.093)$

$0.250(0.108,0.478)$

$0.038(0.002,0.403)$

$0.200(0.133,0.290)$

$0.333(0.231,0.455)$

$0.200(0.066,0.470)$

$0.023(0.001,0.277)$

$0.150(0.102,0.216)$

$0.463(0.380,0.547)$

$0.077(0.011,0.391)$

$0.120(0.039,0.313)$

$0.111(0.054,0.215)$

$0.275(0.170,0.412)$

$0.283(0.215,0.361)$

$0.194(0.143,0.257)$

$0.124(0.070,0.210)$

$0.273(0.090,0.586)$

$0 / 30$

$0 / 78$

$5 / 20$

$0 / 12$

$20 / 100$

$22 / 66$

$3 / 15$
$0 / 21$

$23 / 153$

$62 / 134$

$1 / 13$

$3 / 25$

$7 / 63$

$14 / 51$

$41 / 145$

$36 / 186$

$11 / 89$

$3 / 11$

Overall $\left(I^{\wedge} 2=78.89 \%, P<0.001\right) \quad 0.189(0.137,0.253) \quad 251 / 1212$

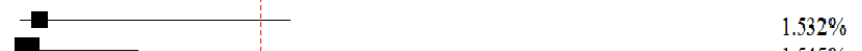

\begin{tabular}{r|r}
$-1.532 \%$ \\
$1.545 \%$
\end{tabular}
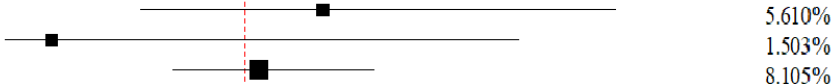

$8.006 \%$

$4.576 \%$

$1.523 \%$

$8.310 \%$

$8.722 \%$

$2.515 \%$

$4.799 \%$

$6.677 \%$

$7.516 \%$

$8.641 \%$

$8.632 \%$

$7.437 \%$
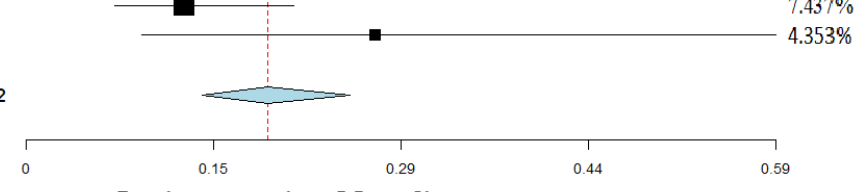

Logit proportion, Mortality

Figure 3 Forest plot of effect of tocilizumab on increase in clinical improvement in COVID 19 patients

\section{Studies}

Patel A, 2020

Betul Borku Uysal 2020

Paola Toniatia, 2020

John Knorr 2020

Pan Luo 2020

Xiaoling Xua 2020

Christina C. Price 2020

Shoji Hashimoto1 2020

Rand Alattar1 2020

Valentina Morenab 2020

Russell M. Petrak 2020

Daria S. Fomina 2020

Casey A. Rimland 2020
Estimate, 95\% CI Events/Total

$0.750(0.522,0.892) \quad 15 / 20$

$0.833(0.523,0.958) \quad 10 / 12$

$0.770(0.678,0.842) \quad 77 / 100$

$0.288(0.192,0.408) \quad 19 / 66$

$0.733(0.467,0.896) \quad 11 / 15$

$0.977(0.723,0.999) \quad 21 / 21$

$0.627(0.548,0.700) \quad 96 / 153$

$0.923(0.609,0.989) \quad 12 / 13$

$0.360(0.199,0.560) \quad 9 / 25$

$0.608(0.469,0.731) \quad 31 / 51$

$0.483(0.403,0.564) \quad 70 / 145$

$0.708(0.605,0.793) \quad 63 / 89$

$0.182(0.046,0.507)$

Overall $\left(I^{\wedge} 2=83.7 \%, P<0.001\right) \quad 0.621 \quad(0.508,0.722) \quad 436 / 721$

Rrandom effects, $95 \%$ confidence interval

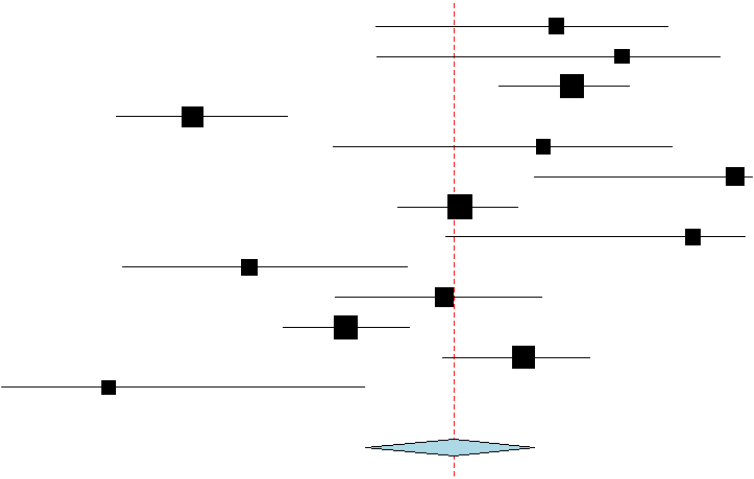

Weights

$7.360 \%$

$5.100 \%$

$10.213 \%$

$9.895 \%$

$6.699 \%$

$2.187 \%$

$10.780 \%$

$3.529 \%$

$8.399 \%$

$9.750 \%$

$10.787 \%$

$10.254 \%$

$5.048 \%$ 
medRxiv preprint doi: https://doi.org/10.1101/2020.08.12.20173682; this version posted August 15, 2020. The copyright holder for this preprint (which was not certified by peer review) is the author/funder, who has granted medRxiv a license to display the preprint in perpetuity.

It is made available under a CC-BY-ND 4.0 International license.

Figure 4 Forest plot of effect of tocilizumab on reduction in need for mechanical ventilation in COVID 19 patients

\section{Rrandom effects, $95 \%$ confidence interval}

Studies

Patel A 2020

Betul Borku Uysal 2020

Paola Toniatia 2020

John Knorr 2020

Pan Luo 2020

Xiaoling Xua 2020

Christina C. Price 2020

Andrew Ip 2020

Rand Alattar 2020

S. Sciascia 2020

Valentina Morenab 2020

Russell M. Petrak 2020

Miguel Górgolas 2020

Daria S. Fomina 2020

Casey A. Rimland 2020
Estimate, 95\% CI Events/Total

$0.550(0.336,0.747)$

$0.167(0.042,0.477)$

$0.030(0.010,0.089)$

$0.152(0.084,0.259)$

$0.067(0.009,0.352)$

$0.095(0.024,0.311)$

$0.052(0.026,0.101)$

$0.216(0.155,0.294)$

$0.280(0.140,0.482)$

$0.032(0.008,0.118)$

$0.275(0.170,0.412)$

$0.234(0.173,0.310)$

$0.081(0.049,0.129)$

$0.169(0.104,0.261)$

$0.455(0.203,0.732)$
$11 / 20$

$2 / 12$

$3 / 100$

$10 / 66$

$1 / 15$

$2 / 21$

$8 / 153$

$29 / 134$

$7 / 25$

$2 / 63$

$14 / 51$

$34 / 145$

$15 / 186$

$15 / 89$

$5 / 11$

Overall $\left(\left.\right|^{\wedge} 2=81.32 \%, P<0.001\right) \quad 0.158(0.107,0.227) \quad 158 / 1091$

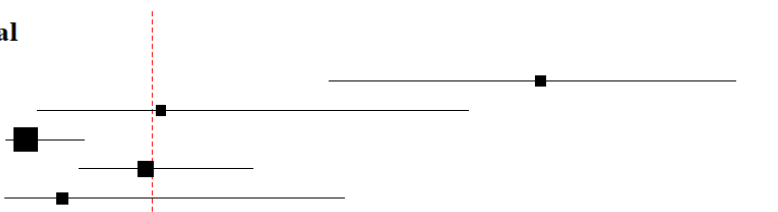

\begin{tabular}{l|l}
$-3.229 \%$ \\
\hline$-3.730 \%$
\end{tabular}

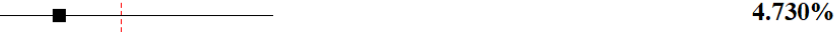

$7.593 \%$

$8.692 \%$

$6.930 \%$

$\mathbf{4 . 8 8 9 \%}$

$7.977 \%$

$8.773 \%$

$8.302 \%$

$\mathbf{8 . 2 0 3 \%}$

$5.676 \%$

Figure 5 Funnel plot of case series studies regarding clinical efficacy in tocilizumab by Egger test

Bias assessment plot

Bias assessment plot

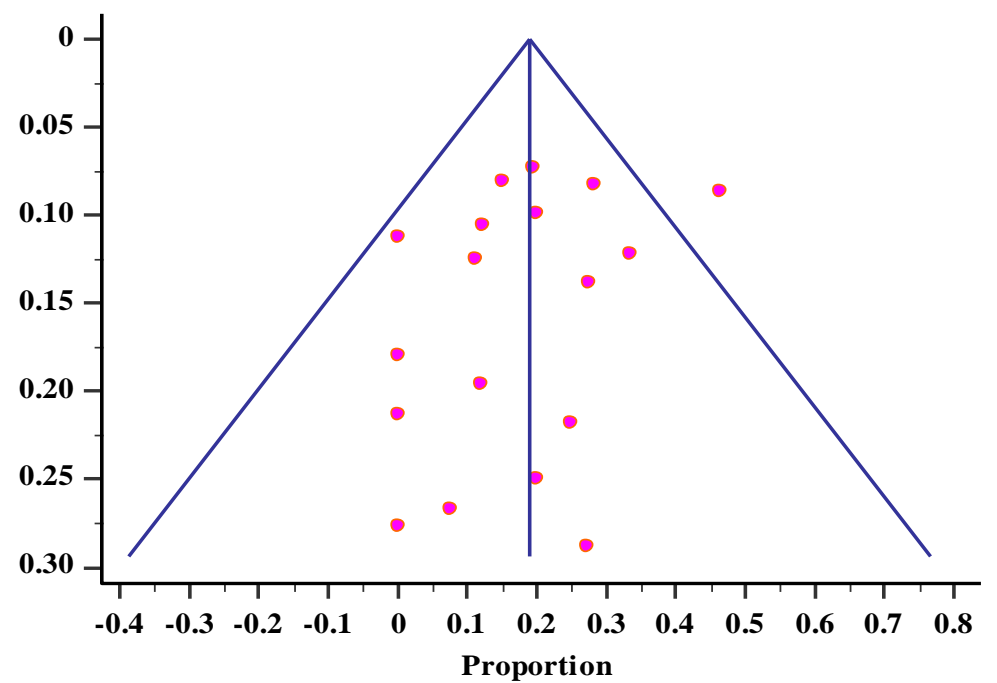

